\title{
粗視化分子動力学法を用いたナノフィラーによる架橋ゴムの 補強における界面効果の研究*
}

柳生 裕聖 ${ }^{* 1}$

\section{Study of interfacial effect on reinforcement of nanofilled crosslinked rubber using coarse-grained molecular dynamics}

\author{
Hiromasa YAGYU ${ }^{* 1}$ \\ ${ }^{* 1}$ Kanto Gakuin Univ. Division of Mechanical Engineering \\ 1-50-1, Mutsuura-higashi, Kanazawa-ku, Yokohama, 236-8501 Japan
}

\section{Received 12 October 2013}

\begin{abstract}
In this paper, modeling and simulation of nanofilled crosslinked rubber using beads spring model was reported, and the effects of the crosslinking density, the dispersibility of nanofiller and the strength of filler-polymer interactions on the reinforcement in an elongation simulation were discussed. The models were consisted two fillers, five polymer-chains, and crosslinkers with four types of filler-rubber interaction based on the Lennard-Jones potential. From the uniaxial elongation simulation, it was confirmed that the strength of interaction was affected to the stress. Furthermore, the dependency of the elongation stress and the mobility of polymer beads around filler on temperature was carried out, and it was found that the presence of low-mobility phase around filler by a strong interaction lead to the reinforcement of filled crosslinked rubber.
\end{abstract}

Key Words : High polymer materials, Molecular simulation, Composite material, Molecular dynamics, Interface

\section{1. 緒言}

高分子マトリクス中にカーボンブラックやシリカなどのフィラーを充填したゴム複合材料は弾性率向上などの 補強性を示す(Kraus, 1965; Wang, 1998). フィラーによる補強性はフィラーの充填量や種類が影響し，その効果は 体積効果，表面効果，空隙効果から構成されていると考えられており，ゴム分子とフィラー表面間の物理・化学的 な相互作用の寄与による表面効果は補強性に顕著な影響を示す。例えば同じサイズのカーボンブラック，グラフ アイトを充填した架橋ゴムの伸張挙動は，同じひずみ量で比較するとカーボンブラックを充填したゴムはグラフ アイトを充填した場合に比べ高い伸張応力を示す。一般にフィラーとゴム分子間の相互作用の強さはフィラーの 表面特性やゴム分子の末端基の種類によって変化する(Ismail, et al.; 1995, Suzuki, et al., 2005). カーボンブラックと ゴム分子間の相互作用の強さは, 未加硫ゴムでは溶媒抽出により得られるバウンドラバーの重量測定(Stickney and Falb, 1964), 架橋ゴムでは動的粘弾性測定における温度分散(Droste and Dibenedetto, 1969; Ziegel, 1969)や NMR 測定 (Mansencal et al., 2001)により評価されている. 近年ではAFMによるカーボンブラック周辺のゴムの弾性率測定 (Lapra, et al., 2003)からカーボンブラック周囲に形成されたゴム層の厚さを算出することにより相互作用の強さの 評価も可能である。ゴムの補強性の評価はフィラーの種類やサイズの異なる試料を用いた力学物性の測定により 評価されるが，ゴム中に充填されたフィラーの状態はそのサイズ，ストラクチャ，表面状態が複雑に関連し，実 験により表面状態（相互作用）の補強性への影響だけを評価することは不可能である.

上記のような課題は分子動力学法による解析により解決できる可能性がある．高分子における分子動力学では すべての分子構造を厳密に再現したフルアトムモデルや簡素化された分子鎖を用いる粗視化モデルが利用されて いる．工業用ゴムは分子量が数十万を有する高分子とサイズが数十 $\mathrm{nm}$ のフィラーの複合材料であり，高分子鎖

\footnotetext{
* 論文 No.13-00746 [DOI: 10.1299/transjsme.2014cm0032]

*1 正員, 関東学院大学 (下 236-8501 神奈川県横浜市金沢区六浦東 1-50-1)

E-mail: yagyu@kanto-gakuin.ac.jp
} 
とフィラーのスケールの違い，計算機の性能や計算時間の制約を考慮すると，フルアトムモデルを用いてフィラ ーとゴム分子間の相互作用と力学物性の関係を解析することは実用的ではない。したがって本論文では Kremer-Grest 鎖（ビーズスプリングモデル）を用いた粗視化分子動力学法を検討した. ビーズスプリングモデル を用いた粗視化分子動力学シミュレーションでは 1 つのビーズを数モノマの集団として扱うため, 化学種に起因 する要素は表現できないが分子の配置や分子間の相互作用を設定することで，マクロスケールの動力学解析が可 能である(Kremer and Grest, 1990). したがって，この手法をフィラー充填架橋ゴムに適用することで，フィラーと ゴム分子間の相互作用の強さと伸張応力の定性的な関係が評価できると考えられる.

フィラーを用いた高分子複合材料の粗視化分子動力学解析に関する研究ではゴム分子を構成するビーズと比較 して直径の大きな 1つビーズをフィラーとしてモデル化したものや (liu, et al., 2011; Adnan, et al., 2007; Smith, et al., 2003), 多数のビーズにより球体に近い形状にフィラーをモデル化した例 (Smith et al., 2002; Cho and Sun, 2007) が 報告されているが，フィラーを充填した架橋高分子はモデル化されていない. また複合材料の界面特性の分子動 力学解析については界面近傍だけに注目しフルアトムモデルを用いた詳細な解析(Katti et al., 2006)などが報告さ れているが，巨視的な空間におけるフィラーが充填された架橋ゴムをモデル化し，さらにフィラーとゴム分子間 の相互作用と伸長挙動などの大変形における力学物性をフィラーとゴム分子の界面挙動に注目し解析した研究は ほとんどない.

本論文ではビーズスプリングモデルを用いてフィラービーズとポリマビーズ間の Lennard-Jones ポテンシャル におけるカットオフ值を調整することにより，フィラーとゴム分子間の相互作用の強さの異なるフィラー充填架 橋ゴムモデルを作成した，さらに，フィラーによる補強効果を明らかにするために，これらのモデルを用いてフ イラーとゴム分子間の相互作用の強さと一軸伸張挙動の関係, およびポリマ分子の運動性について評価した結果 を報告する。

\section{2. ビーズスプリングモデル}

ビーズスプリングモデル(Kremer and Grest, 1990)では 1 つのビーズには数十個の原子が含まれると考え, 以下の ポテンシャル $U(r)$ を有するビーズによって構成される高分子鎖を使用する.

$$
U(r)=U_{b}(r)+U_{n b}(r)
$$

ここで, $r$ はビーズ間距離であり, 結合伸縮ポテンシャル $U_{b}(r)$ と非結合相互作用ポテンシャル $U_{n b}(r)$ は以下の ものを用いる.

$$
\begin{aligned}
& U_{b}(r)=\frac{1}{2} k\left(r-r_{0}\right)^{2} \\
& U_{n b}= \\
& \begin{cases}4 \varepsilon_{i j}\left[\left\{\left(\frac{\sigma_{i j}}{r_{i j}}\right)^{12}-\left(\frac{\sigma_{i j}}{r_{i j}}\right)^{6}\right\}-\left\{\left(\frac{\sigma_{i j}}{c}\right)^{12}-\left(\frac{\sigma_{i j}}{c}\right)^{6}\right\}\right], & (r \leq c) \\
0, & (r>c)\end{cases}
\end{aligned}
$$

ここで, $k$ は結合のバネ定数, $r_{0}$ はビーズの平衡結合長である. $\sigma_{i j}$ と $\varepsilon_{i j}$ はビーズ $i$ とビーズ $j$ 間の Lennard-Jones ポテンシャルに関するパラメータ, $c$ はカットオフ值である. 本研究では結合伸縮ポテンシャル $U_{b}(r)$ として Harmonic ポテンシャルを使用した. 一般に Kremer-Grest 鎖では FENE ポテンシャルが結合伸縮ポテンシャルとし て使用される(Kremer and Grest, 1990). FENE ポテンシャルでは微小な伸張領域において結合長の 2 乗に比例して 増加するポテンシャルとなるが，最大結合長が設定される．したがってゴムのような大変形や架橋構造を扱うシ ミュレーションでは, 結合間に大きな力が作用寸る可能性があるため, 結合長の制限が無い Harmonic ポテンシャ 
ルが適している. Harminic ポテンシャルは寸でに架橋ゴムモデルに使用されており，そのモデルは伸張シミュレ ーションにおいてガウス鎖理論に従う挙動を示すことが報告されている(Hayakawa et al., 2005). 本論文ではモデ ルの架橋構造は直鎖高分子と架橋剤間の結合反応によって生成されるので，結合ポテンシャルとして FENE ポテ ンシャルを使用した場合, 結合間に大きな力が作用し計算が中断される可能性がある. 非結合ポテンシャルエネ ルギ $U_{n b}(r)$ はビーズ間距離が $r$ のときの非結合相互作用であり, Lennard-Jones ポテンシャルで表現される. これ らのポテンシャルを用いたビーズスプリングモデルにおいて位置 $r_{i}$ におけるビーズの運動は Langevin 方程式によ って計算される。

$$
m \frac{d^{2} r_{i}}{d t^{2}}=-\frac{\partial U(r)}{\partial r_{i}}-\Gamma \frac{d r_{i}}{d t}+W_{i}(t)
$$

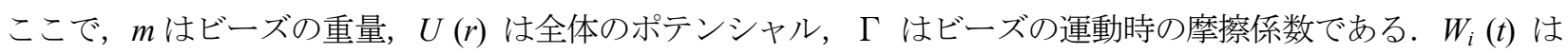
以下の式で定義されるガウスの白色ノイズを表す。

$$
<W_{i}(t) W_{i}\left(t^{\prime}\right)>=2 k_{B} \operatorname{Tm} \Gamma \delta_{i j} I \delta\left(t-t^{\prime}\right)
$$

ここで, $\delta$ はデルタ関数, $T$ は温度, $k_{B}$ はボルツマン定数, $I$ は単位行列である. また計算された值は $\sigma, \varepsilon, m$ を それぞれ長さ, エネルギ, 重量の単位とすることにより無次元化され, 時間と温度の単位はそれぞれ $\tau\left(=\sigma(m / \varepsilon)^{1 / 2}\right)$, $\varepsilon / k_{B}$ となる. なお本論文では摩擦係数は $\Gamma=0.5 \tau^{-1}$ に設定し, 運動方程式はタイムステップ $\Delta t=0.01 \tau$ で velocity Verlet アルゴリズムにより計算される.すずての計算は温度, 体積を一定に制御する NVT アンサンブル, 密度 $0.85 \mathrm{~m} / \sigma^{3}$ の条件で汎用粗視化分子動力学シミュレータ OCTA/COGNACを用いて実施した(Aoyagi, et al., 2002).

\section{3. フィラー充填架橋ゴムモデル}

図 1 にフィラー, ゴム分子, 架橋剤モデルを示寸. フィラーモデル (図 1-(a)) は正二十面体構造とし, 561 個 のビーズ P が結合した中実構造とした．中実フィラーモデルとすることでフィラーの回転運動を考慮することが 可能である. また直径の大きな 1 つのビーズをフィラーとしてモデル化した場合 (liu, et al., 2011; Adnan, et al., 2007; Smith, et al., 2003)，フィラーとゴム分子を構成するビーズの相互作用はビーズ間の中心間距離だけに依存す るので，ゴム分子がフィラー上に吸着した位置を特定できない．さらにフィラー表面をゴム分子が滑ることを許 してしまうため，相互作用の影響を正確に評価できない，本研究ではフィラーモデルとして，できるだけ球体に 近い形状であり, サイズが変化しても形状が変化しない構造体として正二十面体を選択した．正二十面体は球に 近い形状であり，シェル構造を有するので表面のビーズを除去することでサイズの小さい正二十面体を容易に得 ることが可能なため，フィラーサイズの影響を解析する場合にサイズの影響だけを評価できる．フィラーモデル はカーボンブラックなどの無機充填剤を想定し，シミュレーション中に変形しないものとするために，ビーズ間 の結合は著しく大きなバネ定数 $k_{(\mathrm{P}-\mathrm{P})}=2000 \varepsilon / \sigma^{2}$ に設定し, 1 つのビーズについて最大 12 個のビーズを結合させた. なお各ビーズ間の平衡結合距離は $r_{0}=1.0 \sigma$ とした．ゴム分子モデル（図 1-(b)）は 613 個のビーズ $\mathrm{A}, \mathrm{B}, \mathrm{C}$ (ポリ マビーズ）による直鎖であり, 最終的に架橋構造を作成するため, 架橋剤ビーズ $\mathrm{S}$ と反応が可能なビーズ $\mathrm{A}, \mathrm{C}$ （A：末端ビーズ， C : 非末端ビーズ）と反応しないビーズ B が交互に結合した構造とした。 なお架橋反応が可 能なビーズの配位数は末端ビーズ A が 2, 非末端ビーズ C が 3, すなわちビーズ A と B はそれぞれ 1 つの架橋剤 と反応可能である. またビーズ間の平衡結合距離は $r_{0}=1.0 \sigma$, ビーズ A と B, ビーズ B と C 間のバネ定数は $k_{(\mathrm{A}-\mathrm{B})}=k_{(\mathrm{B}-\mathrm{C})}=200 \varepsilon / \sigma^{2}$ とした. 架橋剤ビーズ $\mathrm{S}$ （図 1-(c)）の配位数は 2 に設定し，架橋結合後にはゴム分子と同じ特 性（バネ定数 $\left.k_{(\mathrm{S}-\mathrm{A})}=k_{(\mathrm{S}-\mathrm{C})}=200 \varepsilon / \sigma^{2}\right)$ を与えた. 
(a)

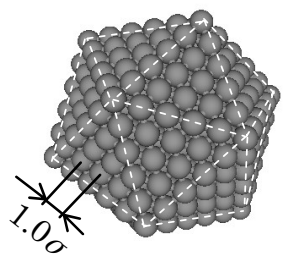

(b)

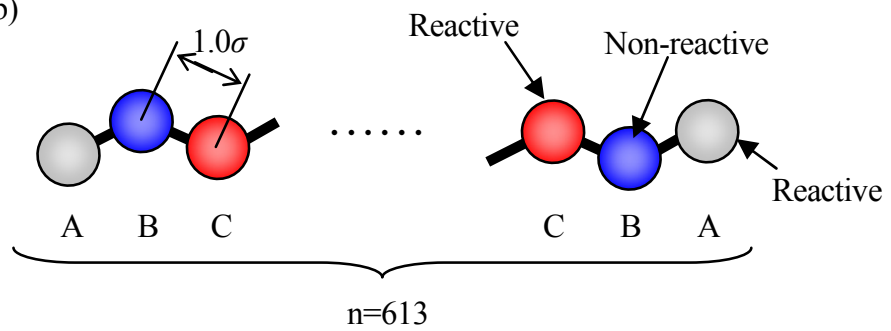

(c)

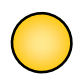

Fig. 1 Icosahedron nanofiller model with 561 beads (a), linear polymer-chain model consisting of the type A bead with one residual bond for reaction, the type $\mathrm{B}$ bead with a saturated bond, and the type $\mathrm{C}$ bead with one residual bonds for reaction (b), and a crosslinker model (c).

図 2 に解析モデルの作成フローを示寸. 最初にセル内にフィラーモデル（P516）2 個，ゴム分子モデル （A1(B1C1)305B1A1） 5 本を密度 $0.85 \mathrm{~m} / \sigma^{3}$ となるように配置するためのセルサイズを算出する．次に計算された サイズ，周期境界条件を有するセルにビーズ $\mathrm{P}$ を正二十面体構造となるように配置し，座標を固定した状態でビ ーズ P 間を結合させる（図 2-(a)）。一方，予めゴム分子についても同じサイズのセルに 5 本のゴム分子

(A1(B1C1)305B1A1）を設置する．続いて作成したフィラーモデルとゴム分子モデルを用い座標を調整しながら 2 個のフィラーとゴムモデルを同じセル内に設置する。この状態では, 粒子とゴム分子が重なり緩和計算が不可 能となるため, python スクリプトを用いフィラーを避けるようにゴム分子をランダムウォークにより再配置する

(図 2-(b))．さらにフィラーの座標を固定し，非結合相互作用を設定した状態でNVT アンサンブルを用いてゴム 分子の緩和計算を 50 万ステップ $(5000 \tau)$ 実施する. 最後にフィラーの座標固定を解除し再度緩和計算を 50 万ス テップ $(5000 \tau)$ 実施する (図 2-(c))．次に架橋ゴムモデルを作成するためにフィラーを避けるように架橋剤ビー ズ $\mathrm{S}$ をセル内へランダムな位置に配置させる.架橋剤ビーズ $\mathrm{S}$ とポリマビーズ $\mathrm{A}$ および $\mathrm{C}$ の架橋結合は COGNAC の REACT 機能を用いて生成し，ビーズ間距離が $1.1 \sigma$ 以下になると結合する設定で NVT アンサンブル計算を行 った. 配置する架橋剤ビーズ S の数 $N v$ は 25 200 個とし架橋密度, 架橋点間分子量の異なる架橋ゴムモデルを 作成した（図 2-(d))。なお計算におけるタイムステップは $0.01 \tau$ とし，フィラーの体積分率は約 $26 \mathrm{vol} \%$ でる.

Lennard-Jones ポテンシャルに関するパラメータはフィラーモデルでは $\sigma_{i j}=1.0 \sigma, \varepsilon_{i j}=4.0 \sigma$, ゴム分子モデルでは $\sigma_{i j}=1.0 \sigma, \quad \varepsilon_{i j}=1.0 \sigma$ に設定した. 実際のフィラーは表面活性が高く容易に凝集するので，上記パラメータはゴム分 子を除いたフィラーだけのシミュレーションにおいて 2 つのィラーが凝集する值を選択した. 表 1 に本モデル で用いた非結合ビーズ間の Lennard-Jones ポテンシャルパラメータを示寸. ここでカットオフ值 $c$ はビーズが相互 作用を及ぼす範囲を表し，ビーズの非結合間距離 $r$ が $r<2^{1 / 6} \sigma$ の範囲ではビーズ間の相互作用は斥力（repulsive） が支配的となる. 寸なわちフィラーとゴム分子に作用する力は $c=2^{1 / 6} \sigma$ では斥力だけとなりカットオフ值 $c$ が大き くなるに従い引力（attractive）の作用が増加する．本モデルではゴム分子を構成するビーズ A, B, C および架橋剤 $\mathrm{S}$ とフィラーを構成するビーズ $\mathrm{P}$ 間のカットオフ值を相互作用パラメータとして変化させた.

(a)

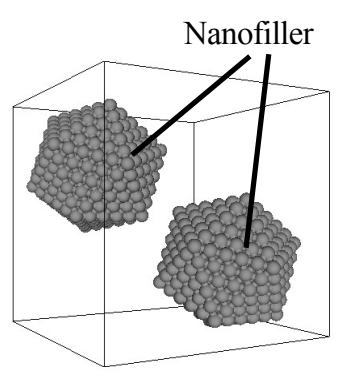

(b)

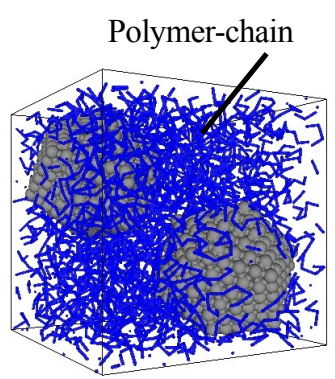

(c)

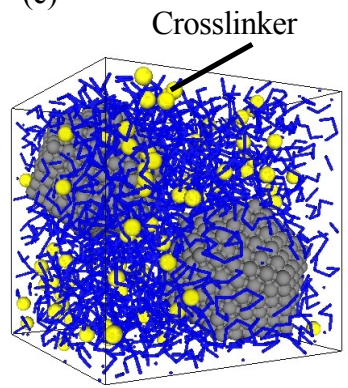

(d)

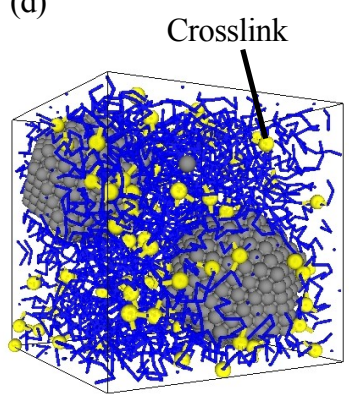

Fig. 2 Modeling flow for the filled crosslinked polymer 
Yagyu, Transactions of the JSME (in Japanese), Vol.80, No.810 (2014)

Table 1 The parameters and cutoff distance of the Lennard-Jones potential.

\begin{tabular}{cccc}
\hline Pair of beads & $\sigma_{i j}$ & $\varepsilon_{i j}$ & $c$ \\
\hline P-P & $1.0 \sigma$ & $4.0 \varepsilon$ & $2.5 \sigma$ \\
P-X* & $1.0 \sigma$ & $2.0 \varepsilon$ & $2^{1 / 6} \sigma-2.5 \sigma$ \\
$\mathrm{X}^{*}-\mathrm{X}^{*}$ & $1.0 \sigma$ & $1.0 \varepsilon$ & $2.0 \sigma$ \\
\hline
\end{tabular}

$\mathrm{X}^{*}=\mathrm{A}, \mathrm{B}, \mathrm{C}$ and $\mathrm{S}$

\section{4. モデルの評価}

\section{$4 \cdot 1$ ゴム分子の分布}

本モデルではフィラーとゴム分子間の相互作用パラメータによりフィラーへのゴム分子の吸着量が変化する. 解析モデルにおけるフィラー表面のゴム分子の濃度を把握するために, フィラー周囲のポリマビーズの動径分布 関数を算出した. 図 3 に架橋剂数 $N v=100$ に設定したモデルにおけるフィラー中心を基準としたポリマビーズの 動径分布関数を示寸. 相互作用パラメータ $c$ が大きくなる（相互作用が強く）に従いフィラー表面付近 $(r=5 \sigma)$ でゴム分子の濃度が高くなり, 吸着量が増加していることが確認できる.

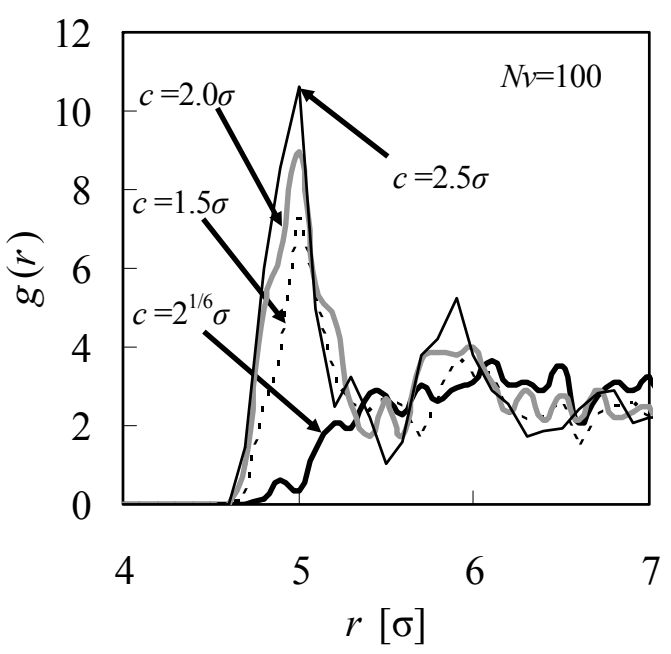

Fig. 3 Radial distribution functions of the polymer beads around the nanofiller $g(r)$ in the filled crosslinked polymer model $(N v=100)$.

\section{$4 \cdot 2$ 架橋構造の評価}

架橋ゴムの力学特性はゴムの架橋構造や架橋密度に依存すると考えられている．このため作成したモデルの架 橋構造を明確にしておく必要がある. 本モデルでは平均架橋点間ビーズ数（現実の架橋ゴムにおける架橋点間分 子量） $M e$ により架橋構造を評価した．図 4 に架橋ゴムモデルとフィラーを充填した架橋ゴムモデルにおける架 橋剂数 $N v$ と平均架橋点間ビーズ数 $M e$ の関係を示す. 架橋剤数 $N v$ が小さい領域ではフィラーを充填することに より平均架橋点間ビーズ数が減少し, 架橋剤数の増加により平均架橋点間ビーズ数 $M e$ が減少する傾向が確認さ れた. また架橋点間を構成する鎖を 1 本の部分鎖と仮定すると, 部分鎖数とセル体積から算出したモデルの架橋 密度は $N v=100$ のとき $0.026 \sigma^{-3}$ と算出された. 図 5 にフィラー充填架橋モデル (フィラーとゴム分子間の相互作用 パラメータ $\left.c=2^{1 / 6} \sigma \sim 2.5 \sigma\right)$ の架橋点間ビーズ数の分布を示す. 本モデルでは架橋点間ビーズ数の值は僅かにビー ズ数の小さい領域に集中していることが確認できる. またフィラーを含有することで架橋点間のビーズ数 $M e=15$ 付近の度数が減少している. これはセル内にフィラーを充填したことでゴム分子の占有する空間が減少したこと が原因と考えられる。 


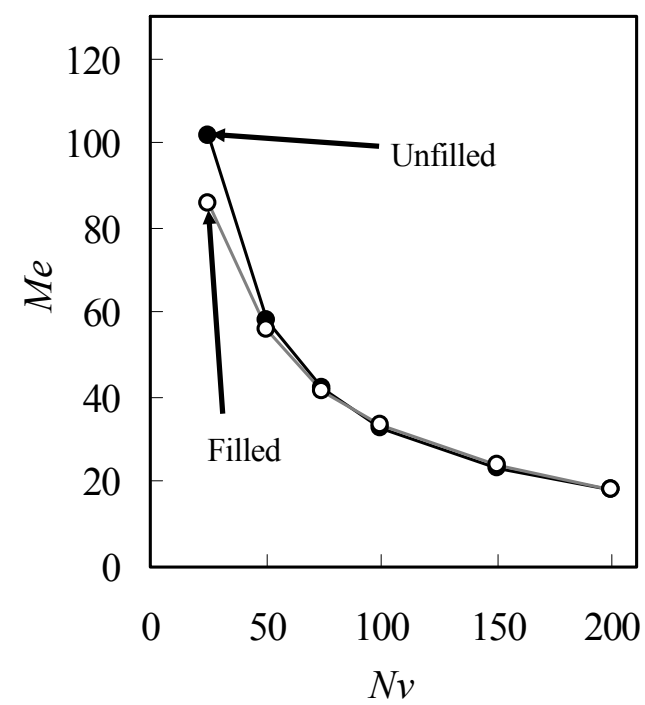

Fig. 4 Average number of beads between crosslinks $(\mathrm{Me})$ as a function of the number of crosslinkers $(N v)$.

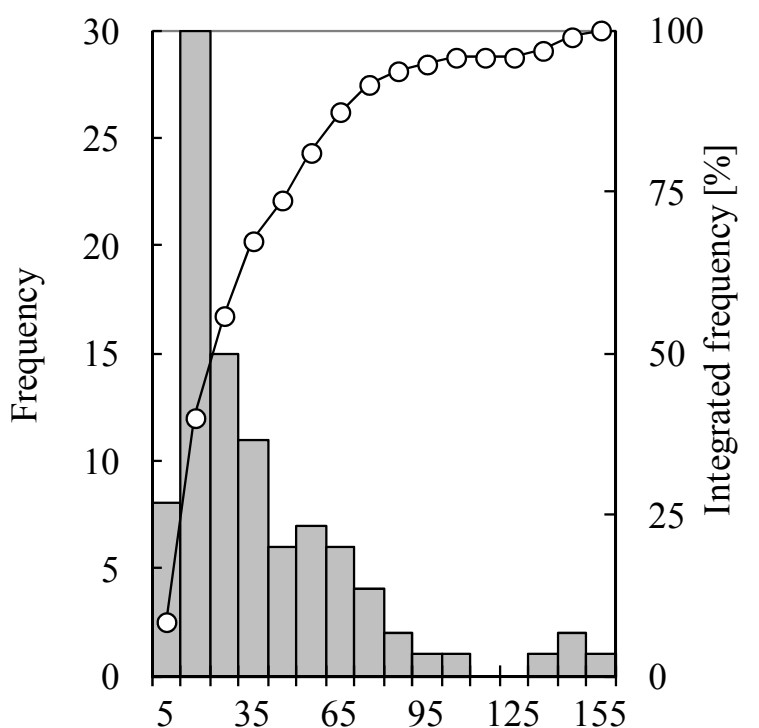

$\mathrm{Me}$

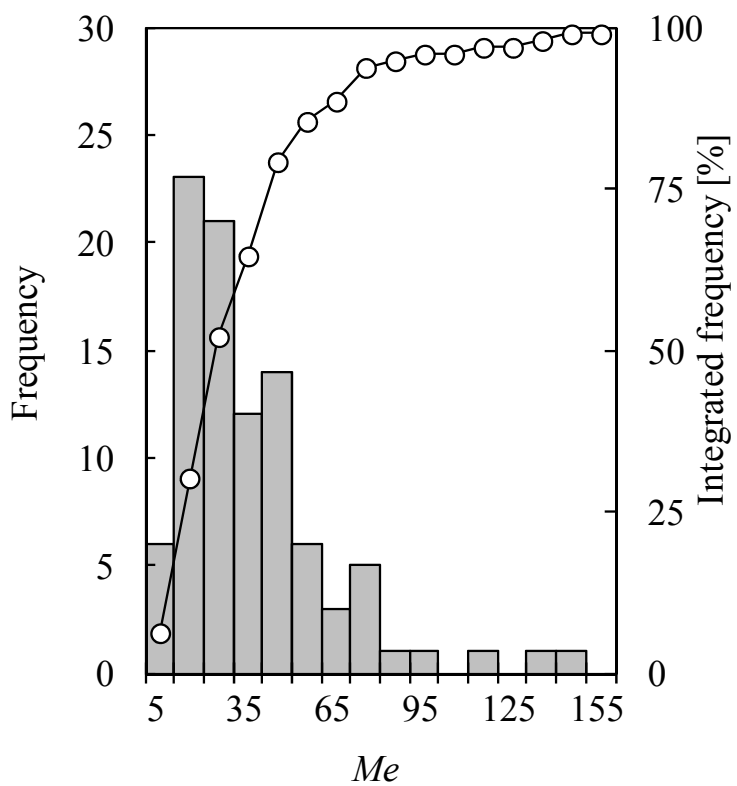

Fig. 5 The distributions of the number of bead between crosslinks in unfilled crosslinked polymer (a) and the filled crosslinked polymer model with $c=2.0 \sigma(\mathrm{b})(N v=100)$.

Table 2 Glass transition temperature Tg calculated by NPT simulation

\begin{tabular}{cc}
\hline Strength of the Interaction & $\mathrm{Tg}$ \\
\hline $2^{1 / 6} \sigma$ & $0.38 \varepsilon / k_{B}$ \\
$1.5 \sigma$ & $0.46 \varepsilon / k_{B}$ \\
$2.0 \sigma$ & $0.46 \varepsilon / k_{B}$ \\
$2.5 \sigma$ & $0.46 \varepsilon / k_{B}$ \\
\hline unfilled & $0.38 \varepsilon / k_{B}$ \\
\hline
\end{tabular}

\section{$4 \cdot 3$ ガラス転移温度}

ゴム材料のガラス転移温度は室温以下の温度領域に存在する．室温におけるゴム材料のシミュレーションを実 施するためにはモデルのガラス転移温度を把握し，その温度より高い温度で伸長計算を実施する必要がある. 本 
研究では NPT アンサンブルを用いて温度降下過程におけるモデルの体積変化からガラス転移温度を算出する手 法を用いてモデルのガラス転移温度 $\mathrm{Tg}$ を評価した. 表 2 に各モデルのガラス転移温度の解析結果を示寸. フィ ラーなし, およびフィラーとゴム分子間の相互作用パラメータが $c=2^{1 / 6} \sigma$ のときガラス転移温度は $\mathrm{Tg}=0.38 \varepsilon / k_{B}$, フ イラーとゴム分子間の相互作用パラメータが $c=1.5 \sigma \sim 2.5 \sigma$ のとき $\mathrm{Tg}=0.46 \varepsilon / k_{B}$ と算出された. したがって本研究で はガラス転移温度 $\left(0.38 \sim 0.48 \varepsilon / k_{B}\right)$ より高い温度である $T=0.75 \varepsilon / k_{B}$ で伸長シミュレーションを実施する.

\section{5. 伸張シミュレーション}

フィラーによる補強効果を確認するため，作成したモデルの一軸伸張シミュレーションを実施した. 最初に架 橋による効果を確認するため異なる架橋密度 $(\approx N v)$ を有するフィラーを充填しない架橋ゴムの一軸伸張シミュ レーションを実施した，なお伸張速度は $3 \times 10^{-2} \sigma / \tau$ (ひずみ速度 $1.8 \times 10^{-3} / \tau$ ), ポアソン比は 0.5 とした. 図 6 に温度 $T=0.75 \varepsilon / k_{B}(>\mathrm{Tg})$ における架橋ゴムモデルの応力-ひずみ曲線を示す. 架橋密度（ $(N v ）$ が増加することにより高 い伸張応力を示すことが確認できる．以上の結果から本架橋ゴムモデルが架橋による補強効果を表現できること が示された. 図 7 に温度 $T=0.75 \varepsilon / k_{B}, N v=100$ におけるフィラー充填架橋ゴムの一軸伸張シミュレーションにお ける応力-ひずみ曲線を示す. フィラーとゴム分子間の相互作用パラメータ $c$ が大きくなるに従い, 高い伸張応力 を示すことが確認できる.すなわちフィラー表面とゴム分子間の相互作用は伸張挙動に影響し，フィラーとゴム 分子間の相互作用が強くフィラー表面へのゴム分子の吸着量が多い条件では高い補強効果を示した. 表 2 に示し たガラス転移温度はフィラーとゴム分子間の相互作用パラメータ $c=1.5 \sigma$ 以上で一定であるが, 伸長挙動は $c=1.5 \sigma$ 以上で異なる．これはガラス転移温度のようにビーズの移動距離の小さい評価ではなく, 伸長挙動のような比較 的ビーズの移動距離の大きな計算ではフィラーとゴム分子間の相互作用 $c=1.5 \sigma$ 以上の拘束力が有効になっている ものと予想される.

次に上記のシミュレーション結果の妥当性を評価するためにフィラー充填架橋ゴムの伸長試験を実施した. 図 8 にカーボンブラック（東海カーボン, シースト 116）とグラファイト（東海カーボン, トーカブラック\#3845) をそれぞれ充填したパーオキサイド架橋 EPDM（Nordel，IP3640）の伸張試験結果（実験結果）を示す。なお図 8 において CB/EPDM はカーボンブラック充填架橋 EPDM, G/EPDM はグラファイト充填架橋 EPDM を示し, カー ボンブラック, グラファイトの平均粒子径は約 $40 \mathrm{~nm}$ であり, 体積分率はシミュレーションモデルに合わせて約 26vol\%とした. カーボンブラックは粒子の表面にカルボキル基などのゴム分子に対して活性な分子を有するため, ゴム分子と強い相互作用を示すことが知られている，一方，グラファイトは表面が結晶化状態にあり，活性な分 子を保有しない. したがって表面活性の高いカーボンブラックを充填したゴム材料はグラファイトを充填したゴ ムに比べ高い補強性を示している. 図 7 に示した相互作用と伸張応力に関寸るシミュレーション結果は図 8 に示 した実駼結果を再現しており，モデルの詳細な解析によりフィラーとゴム分子間の相互作用の強さと補強性の関 係を解明できるものと考えられる.

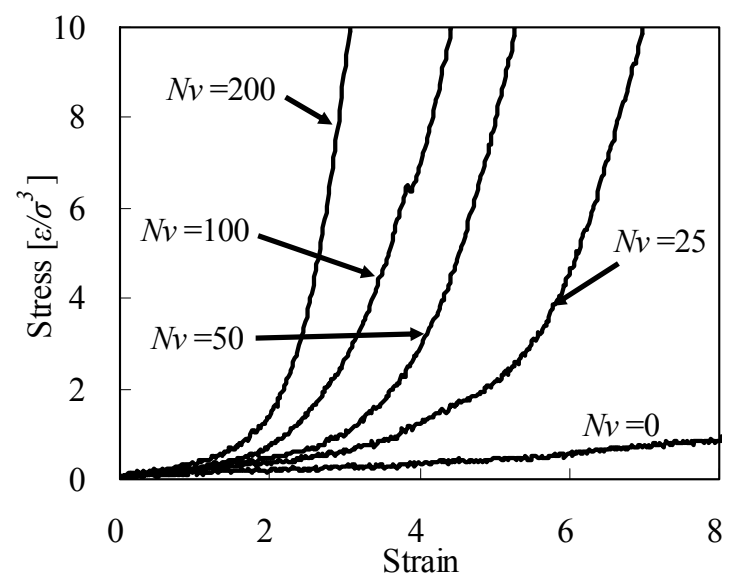

Fig. 6 Stress-strain curves in the uniaxial elongation simulation of the unfilled crosslinked polymer model with the number of crosslinkers $(N v=0,25,50,100$, and 200$)$. 


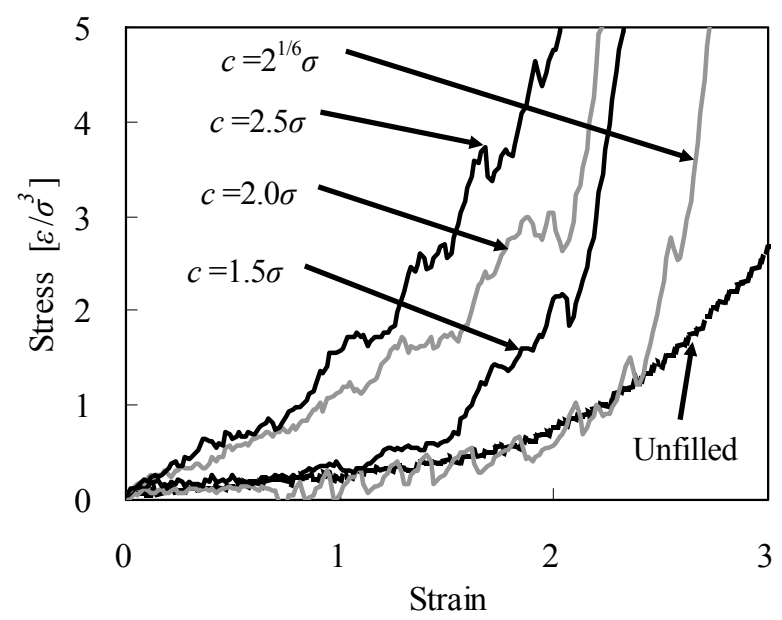

Fig. 7 Stress-strain curves in the uniaxial elongation simulation of the unfilled crosslinked and the filled crosslinked polymer model $(N v=100)$. The cutoff parameter $c$ applied to the filler-polymer interaction was $2^{1 / 6} \sigma, 1.5 \sigma, 2.0 \sigma$, and $2.5 \sigma$.

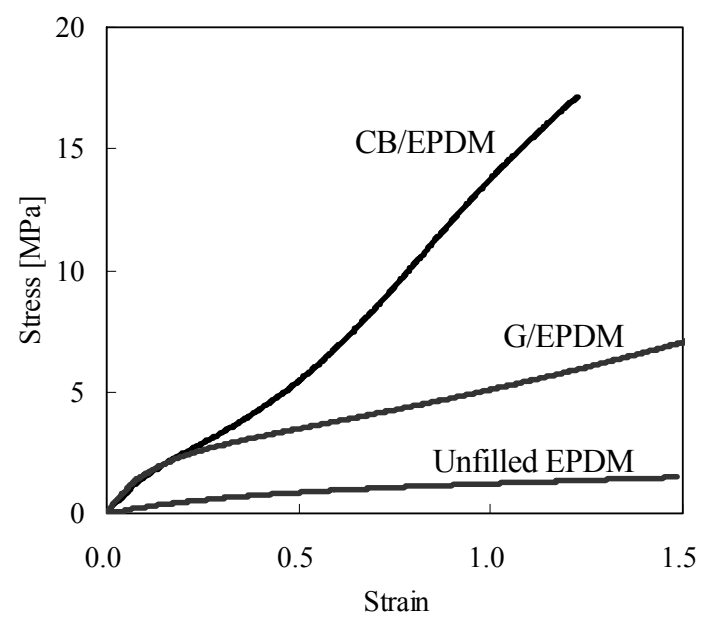

Fig. 8 The experimental stress-strain curves of Carbon black filled crosslinked EPDM (CB/EPDM), Graphite filled crosslinked EPDM (G/EPDM), and Unfilled crosslinked EPDM.

\section{6. フィラー周囲のゴム分子の応力解析}

フィラーとゴム分子間の相互作用と補強性の関係を明らかにするために，モデル（ $N v=100 ）$ の伸張過程におけ るポリマビーズに作用する力を解析した. 図 9 にフィラーとゴム分子間に弱い相互作用 $\left(c=2^{1 / 6} \sigma\right)$ と強い相互作 用 $(c=2.5 \sigma)$ を有するモデルの伸張前後におけるポリマビーズに作用する力の分布を示す．黒い部分は大きな力 が作用しているビーズを示しており, 強い相互作用を有するモデルではフィラー表面付近のポリマビーズに大き な力が作用している.

さらに補強性と相互作用の関係を明らかにするために詳細な解析を行った. 図 10 にフィラー中心からの距離と ポリマビーズに作用する力の関係を示す. 図 10 のプロットは $0 \%$ と $100 \%$ 伸長におけるフィラー中心からの距離 $r$ $\pm 0.5 \sigma$ の範囲に存在するポリマビーズに作用する力の平均值である. 伸張前においてフィラー表面付近のゴム分 子には高い応力が作用しているが，その值は伸張することで増大している。この高い応力はフィラー表面から約 $2 \sigma$ の範囲に作用しており，この範囲はフィラーとゴム分子の相互作用の増加と共に大きくなる傾向を示した. 


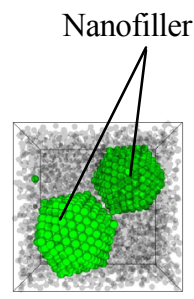

(a) $0 \%$

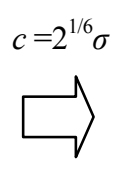

$c=2.5 \sigma$

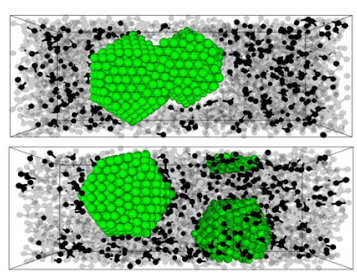

(b) $100 \%$

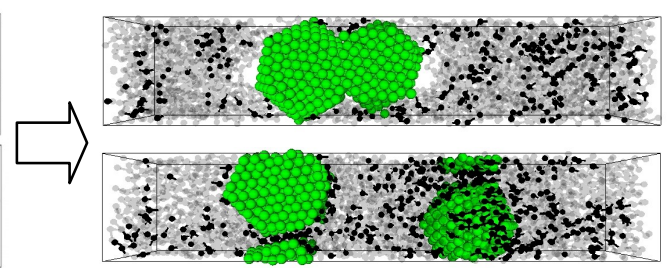

(c) $200 \%$

Fig. 9 Stress distribution of the polymer beads of the filled crosslinked polymer model $\left(c=2^{1 / 6} \sigma\right.$ and $\left.2.5 \sigma\right)$ at an elongation of $0 \%$ (a), $200 \%$ (b), and $200 \%$ (c). The number of crosslinkers was $N v=100$. Black parts show the polymer beads with high stress.
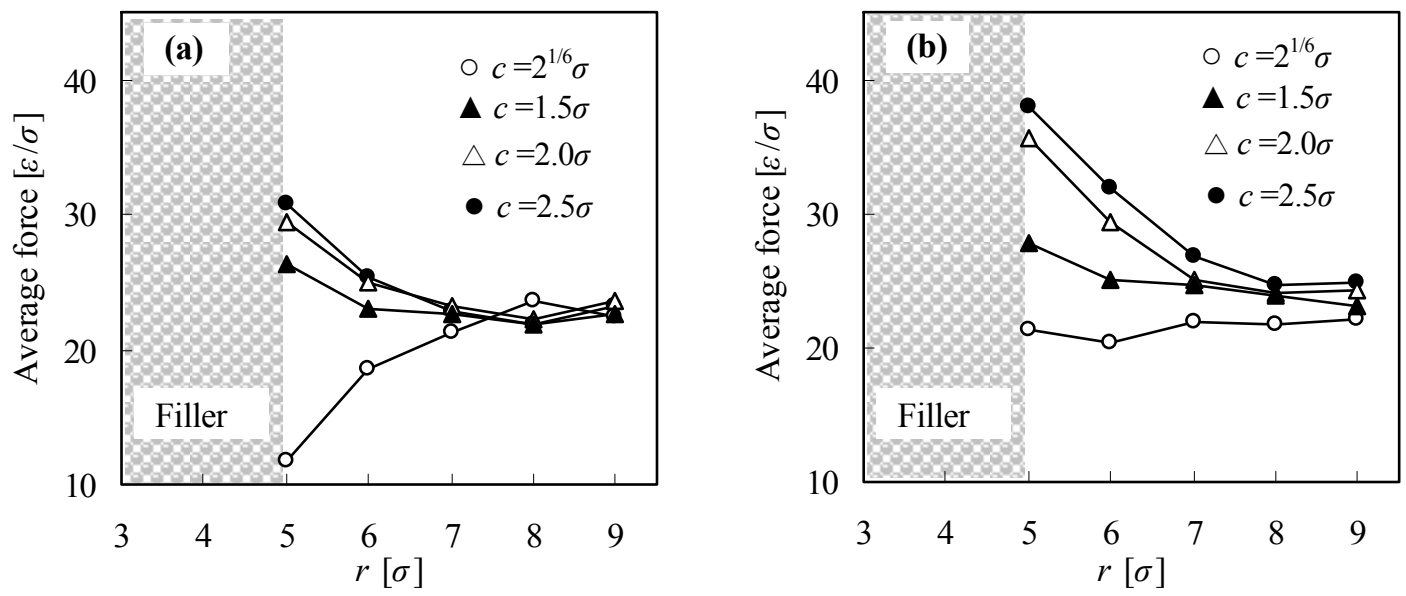

Fig. 10 Average force of the polymer beads as a function of the distance from the center of the nanofiller in the filled crosslinked polymer model at $0 \%$ (a) and $100 \%$ elongation (b). The number of crosslinkers was $N v=100$, and the cutoff parameter $c$ applied to the filler-polymer interaction was $2^{1 / 6} \sigma, 1.5 \sigma, 2.0 \sigma$, and $2.5 \sigma$.

\section{7. フィラー周囲のゴム分子の運動性}

フィラー表面付近のゴム分子に大きな力が作用する理由を把握するために，フィラー周囲のポリマビーズの運

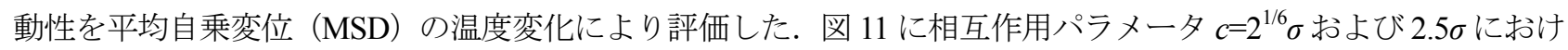
るフィラー中心からの距離 $r=5 \sim 9 \sigma$ に存在するポリマビーズの平均自乗変位（MSD）の温度変化を示す. MSD の温度変化における屈曲点（温度上昇時に MSD が急増し折れ曲がりを示す点）は高分子鎖のガラス転移温度を 示すことが報告されており (Morita, et al., 2006), フィラー表面付近のゴム分子のガラス転移温度 $(r=5 \sigma, 6 \sigma$ の平均 值）は表 3 のように見積もることができる．図 11-(b)のようにフィラー表面から離れた位置のガラス転移温度は 表 2 に近い值を示しているが，フィラー表面付近では高い值を示している. したがって図 7 に示した伸張温度 
$T=0.75 \varepsilon / k_{B}$ において相互作用パラメータ $c=2.5 \sigma$ ではフィラー表面のゴム分子はガラス状態にあることが確認でき る.

ここでフィラー表面のゴム分子の運動性と伸張応力の関係を明らかにするために，伸張応力の温度依存性を解 析した. 図 12 に伸張率 100\%における応力（M100）の温度依存性を示す. 伸張応力は低温領域では相互作用に依 存した高い值を示し，高温領域では相互作用の強さに関わらず徐々に応力が増加する傾向を示した．MSD の温 度変化の評価により算出したフィラー表面付近のゴム分子のガラス転移温度（表 3）がフィラーとゴム分子間の 相互作用により変化する傾向は, 図 12 における応力が変化する温度とほぼ一致することから, フィラー表面から $2 \sigma$ の範囲（ $r=5 \sim 6 \sigma ）$ のゴム分子は非常に低い運動性を示しており，この低い運動性がフィラー周囲に高い応力 を発生させる原因であると考えられる.

さらに本モデルにおけるフィラー直径を $30 \mathrm{~nm}$, 未架橋ゴム分子の分子量を 17 万と仮定するとフィラーモデル の半径方向のビーズ数（直径）と結合長 $\left(r_{0}=\sigma\right)$ の比較から $\sigma=3 \mathrm{~nm}$ と算出される $(10 \sigma=30 \mathrm{~nm})$. したがって, フ イラー（直径 $30 \mathrm{~nm}$ ）周囲の補強性に影響する層の厚さは $6 \mathrm{~nm}$ 程度と見積もることができる. このポリマ層の厚 さは SBR の動的粘弾性測定から算出された值とほぼ一致する(Arighi, et al., 2003).
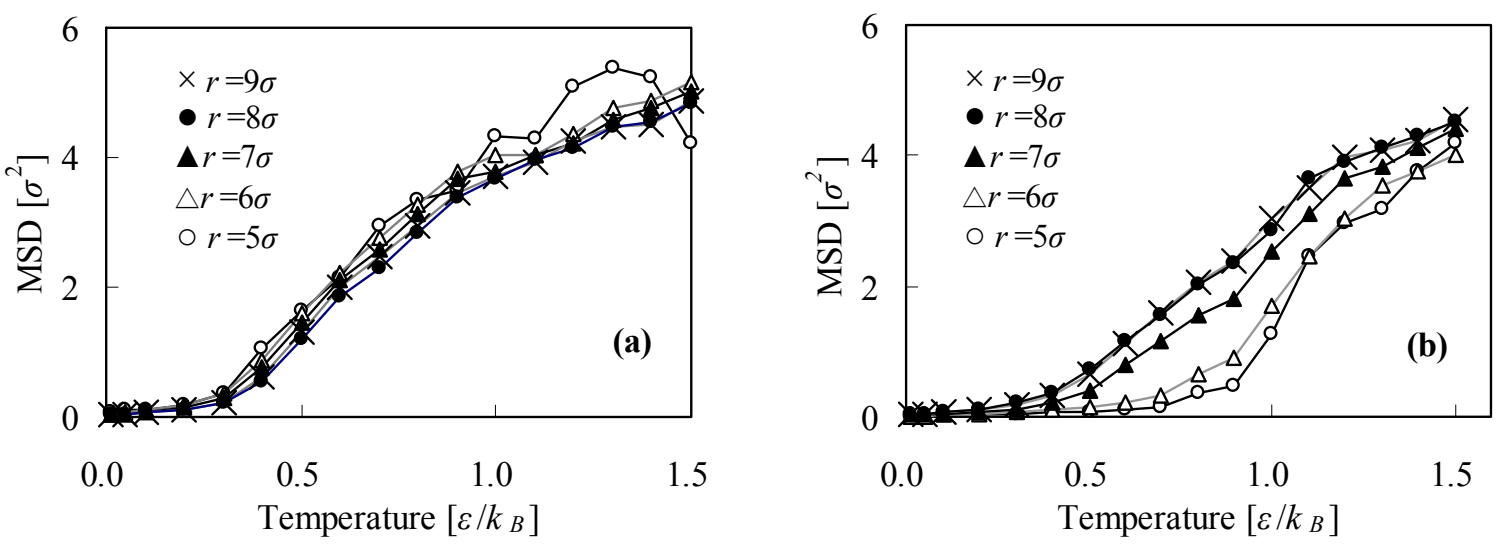

Fig. 11 Mean-square displacement (MSD) at a distance of $5 \sigma$ (nanofiller surface), $6 \sigma, 7 \sigma, 8 \sigma$, and $9 \sigma$ from the center of the nanofiller as a function of temperature for the filled crosslinked polymer model at $0 \%$ elongation. The cutoff parameter $c$ applied to the filler-polymer interaction was $2^{1 / 6} \sigma(a)$ and $2.5 \sigma(b)$.

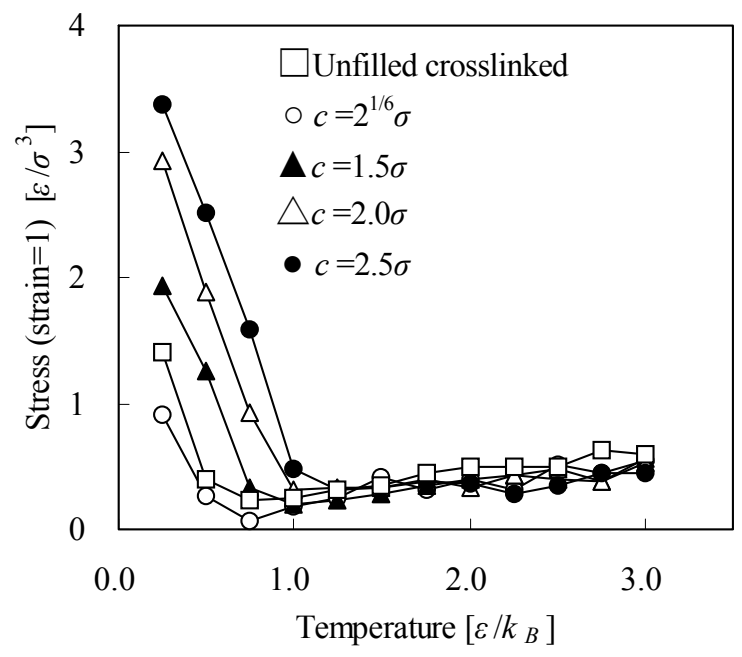

Fig. 12 The relationship between the stress at 100\% strain and the elongation temperature of unfilled and filled model with $N v=100$. 
Table 3 Glass transition temperature Tg of polymer beads near the nanofiller surface (average value of $\operatorname{Tg}$ in $r=5 \sigma$ and $6 \sigma$ ), calculated by MSD

\begin{tabular}{cc}
\hline Strength of the Interaction & $\mathrm{Tg}$ \\
\hline $2^{1 / 6} \sigma$ & $0.4 \varepsilon / k_{B}$ \\
$1.5 \sigma$ & $0.6 \varepsilon / k_{B}$ \\
$2.0 \sigma$ & $0.8 \varepsilon / k_{B}$ \\
$2.5 \sigma$ & $0.9 \varepsilon / k_{B}$ \\
\hline
\end{tabular}

\section{8. 結 論}

ビーズスプリングモデルを用いてフィラーとゴム分子間の相互作用の強さの異なるフィラー充填架橋ゴムモデ ルを作成し，一軸伸張シミュレーションを実施した．伸張シミュレーション結果から，フィラーとゴム分子間の 相互作用が強くなるに従い補強性を示す伸張灾力は増加することが確認された. さらにモデルのフィラー周囲に 存在するゴム分子の運動性を解析した結果, ゴム補強性はフィラーとゴム分子間の相互作用の強さに依存し, 伸 張応力に影響する因子の 1 つはフィラー表面付近の低い分子運動性を有するゴム分子の存在であることが確認さ れた. しかしながら本モデルはフィラー数を 2 個に設定した比較的小規模なモデルであり，フィラーの凝集など のストラクチャが考慮されていない。今後は，セルサイズを拡張した大規模なシミュレーションを実施し，本モ デルの解析結果と比較することにより，本解析モデルの有用性評価やフィラーサイズ，分散状態の補強性への影 響を確認する.

\section{References}

Adnan, A., Sun, C.T., and Mahfuz, H., A molecular dynamics simulation study to investigate the effect of filler size on elastic properties of polymer nanocomposites, Composite Science and Technology, Vol. 67 (2007), pp. 348-356.

Aoyagi, T., Sawa, F., Shoji, T., Fukunaga, H., Takimoto, J., and Doi, M., A general-purpose coarse-grained molecular dynamics program, Computater Physics Communication Vol. 145 (2002), pp. 267-279. See also the web site http://octa.jp.

Arighi, V., McEwen, I.J., Qian, H., and Sterrano, M.B.P., The glass transition and interfacial layer in styrene-butadiene rubber containing silica nanofiller, Polymer, Vol. 44 (2003), pp. 6259-6266.

Cho, J., and Sun, C.T., A molecular dynamics simulation study of inclusion size effect on polymeric nanocomposites, Computational Materials Science, Vol. 41 (2007), pp. 54-62.

Droste, D.H. and Dibenedetto, A. T., The glass transition temperature of filled polymers and its effect on their physical properties, Journal of Applied Polymer Science, Vol. 13 (1969), pp. 2149-2168.

Hayakawa, T., Hashimoto, K., Morita, H., and Doi, M., Investigation of stress-strain relationship for polymer networks with crosslink types by molecular dynamics simulation (OCTA), International Rubber Conference 2005 (2005), G11-11.

Ismail, H., Freakley, P.K., and Sheng, E., Effects of multifunctional additive on mechanical properties of silica filled natural rubber compound, European Polymer Journal, Vol. 31 (1995), pp. 1109-1117.

Katti, K.S., Sikdar, D., Katti, D.R., Ghosh, P., and Verma, D., Molecular interactions in intercalated organically modified clay and clay-polycaprolactam nanocomposites: experiments and modeling, Polymer, Vol. 47 (2006), pp. $403-414$.

Kraus, G.., Reinforcement of elastomers, Wiley, New York (1965).

Kremer, K., and Grest, G.S., Dynamics of entangled linear polymer melts: A molecular-dynamics simulation, Journal of Chemical Physics, Vol. 92 (1990), pp. 5057-5086.

Lapra, A., Clément, F., Bokobza, L., and Monnerie, L., Straining effects in silica-filled elastomer investigated by atomic force microscopy: from macroscopic stretching to nanoscale strainfield, Rubber Chemistry and Technology, Vol. 76 (2003), pp. 60-81. 
Liu, J., Gao, Y., Gao, D. Zhang, L., and Guo, Z., Nanoparticle dispersion and aggregation in polymer nanocomposites: Insights from molecular dynamics simulation, Langumuir, Vol. 27 (2011), pp. 7926-7933.

Mansencal, R., Haidar, B., Vidal, A., Delmotte, L., and Chezeau, J.M., High-resolution solid-state NMR investigation of the filler-rubber interaction, Polymer International, Vol. 50-54 (2001), pp. 387-394.

Morita, H., Tanaka, K., Kajiyama, T., Nishi, T., and Doi, M., Study of the glass transition temperature of polymer surface by coarse-grained molecular dynamics simulation, Macromolecules, Vol. 39 (2006), pp. 6233-6237.

Smith, J.S., Bedrova, D., and Smith, G.D., A molecular dynamics simulation study of nanoparticle interactions in a model polymer-nanoparticle composite, Composite Science and Technology, Vol. 63 (2003), pp1599-1605.

Smith, G.D., Bedrov, D., Li, L., and Byutner, O., A molecular dynamics simulation study of the viscoelastic properties of polymer nanocomposites, Journal of Chemical Physics, Vol. 117 (2002), pp. 9478-9489.

Stickney, P. and Falb, R., Carbon black-rubber interactions and bound rubber, Rubber Chemistry and Technology, Vol. 37 (1964), pp. 1299-1340.

Suzuki, N., Ito, M., and Yatsuyanagi, F., Effects of rubber/filler interactions on deformation behavior of silica filled SBR systems, Polymer, Vol. 46 (2005), pp. 193-201.

Wang, M.J., Effect of polymer-filler and filler-filler interactions on dynamic properties of filled rubber, Rubber Chemistry and Technology, Vol. 71 (1998), pp. 520-589.

Ziegel, K.D., Role of the interface in mechanical. Energy dissipation of composites, Journal of Colloid Interface Science, Vol. 29 (1969), pp. 72-80. 